\title{
METHODS OF SALT CONTENT STABILIZATION IN CIRCULATING WATER SU PPLY SYSTEMS
}

\author{
Volodymyr Shmandiy ${ }^{1, *}$, Lilija Bezdeneznych ${ }^{1}$, Olena Kharlamova ${ }^{1}$, Anatoliy Svjatenko ${ }^{1}$, \\ M yroslav Malovanyy ${ }^{2}$, Kateryna Petrushka ${ }^{2}$, Igor Polyuzhyn ${ }^{2}$
}

https://doi.org/10.23939/chcht11.02.242

\begin{abstract}
The effect of corrosion inhibitors and microbiocides presented in circulating water supply systems on the corrosion rate of structural materials has been studied. It is shown that using the mixture of zinc phosphonates aqueous solutions, special polymeric dispersants and microbicides based on bromine and quaternary ammonium salts provides dissolution of calcium carbonate deposits and the corrosion rate of steel materials at the lowest level. Rational modes of circulating water chemical treatment are proposed, which increase operational reliability. The electrical conductivity of KU-2 resin, which will be used for intermembrane filling during electrodialysis of makeup water in a circulating water supply system has been determined to prevent the salts concentration.
\end{abstract}

Keywords: circulating water supply, corrosion, inhibitor, microbiocides, electrodialysis, intermembrane filling.

\section{Introduction}

The search of new ways to improve quality performance of cycling water supply system at the enterprises to reduce the anthropogenic impact on water basin is an urgent problem. It is necessary to investigate methods of salt content stabilization and methods of corrosion minimization in the mentioned systems. Corrosion processes are hazardous for the environment [1, 2] due to their direct or corroded products and various harmful substances produced as a result of accidents caused by the equipment corrosion.

In certain industrial processes the total salt content and water hardness increase as a result of cooling water

\footnotetext{
${ }^{1}$ Kremenchuk Mykhailo Ostrohradskiy National University, 20, Pershotravneva St., 39600 Kremenchuk, Ukraine;

${ }^{2}$ Lviv Polytechnic National University,

12, S.Bandery St., 79013 Lviv, Ukraine

*sefira@mail.ru

(C) Shmandiy V., Bezdeneznych L., Kharlamova O., Svjatenko A.,

Malovanyy M., Petrushka K., Polyuzhyn I., 2017
}

recirculation in the cycling water supply system. At the same time the system operation is accompanied by a reproduction of microorganisms, bacteria and fungi under calcium deposits on the inner surface of pipelines. The rate of chemical reactions and biological processes, scale formation, corrosion and biofouling increases with increasing temperature of the circulating water [3].

The corrosion processes reduce interrepair time of equipment. Therefore, it is advisable to treat cooling water, and thus reduce its scale-forming and corrosion properties provided by contaminations of mineral and organic origin and operating conditions of current cooling systems. According to Ref. [3-5] corrosion inhibitors and biocides are most useful to restrain deposits formation and the growth of microorganisms. To stabilize the salt content in water and limit the accumulation of salts it is advisable to clean water used to refill the system in order to prevent the salts concentration in the system. Membrane processes, especially electrodialysis, are effective methods of this strategy implementation.

Water from the circulating water supply system contains ions of hardness, sodium, phosphates, chlorides and sulfates. Removal of hardness ions from neutral solutions is well studied $[6,7]$. The results of sulphates removal from water, including electrodialysis, are published in [8-10]. It is important to choose a suitable method of removing these ions. The method described in work [9], makes it possible to separate the chlorides from sulfates by precipitation. Sodium chloride should be converted into alkali and active chlorine via electrodialysis [11]. Electrodialysis with filling intermembrane space by ion-transfer turbulators (granulated ion-exchange materials) is a prospective direction [12]. The role of these ion exchangers is that irreversible dissociation of water occurs at their heteropolar borders with ion-exchange membranes. During dissociation the hydrogen and hydroxyl ions are generated and participate in a continuous electrochemical regeneration of ion exchange materials. Thus they join to the transport of ions of mineral impurities in water. Using gaskets made of insulating materials results in the essential increase of the 
electrodialysis voltage and reduction of the membrane working surface. Therefore, the use of ionites in the form of granules, as an intermembrane filling, is of great interest. But for successful application of gaskets made of insulating material it is necessary to study the electrical conductivity of materials that will be used to fill the intermembrane space. We studied the system of KU 2 ion exchange resin $-\mathrm{NaCl}$ solution.

The aim of this work is a scientific and practical basis and objective assessment of the effect of chemicals on the rate of corrosion and microbes' growth on the inner surface of pipelines and the effect of makeup water in the system using electrodialysis.

\section{Experimental}

As the object of studies we have chosen the circulating water supply system of PJSC "Ukrtatnafta". The unit of circulating water supply is equipped by multisectional mechanical-draft towers and pumping equipment. We carried out bench tests of the circulating water treatment by chemicals to eliminate the scale formation in pipes and heat exchange equipment, and to reduce the corrosion rate of carbon steel.

The test bench is a working model of mechanicaldraft tower which includes a coiled pipe with coupons, tank of $200 \mathrm{dm}^{3}$ by volume, pump, temperature control unit, cooling minitower, flowmeter and heating element. To control the corrosion rate the holder with flat steel coupons made of Steel 3 was placed in the tank. The coupons made of Steel 20 in the form of cylindrical rods were inserted into the coiled pipe and constantly washed under running water. Water heating was controlled by a thermoregulator with a heating element. When passing through the heating element the water is heated and the scale is formed over its surface. Heated water is directed through the system of corrosion control, scale formation (collection of coupons) and sprinkler to the plastic filling of the cooling tower. Filling is cooled by air that is blown into the bottom of the cooling tower. While contacting with the air heated water is cooled due to evaporation. Water level in the main tank is reduced, and it is registered by a level meter. To simulate the evaporation factor $(\mathrm{Ke})$ the balance between evaporated water makeup water and blowing (withdrawal of water from the tank) is maintained.

The tests were carried out in three stages with the duration of 21 days each.

At the first stage we examined the circulating water without adding reagents and microbiocides. Three times a week we picked up samples of circulating water and water from the tank. The set value $\mathrm{Ke}=2.0$ was supported by drainage and adding makeup water. Typical analyses (hardness, alkalinity, salt content, iron content) were performed. The following results were obtained: total hardness $11-21.7 \mathrm{mg}$-eq $/ \mathrm{dm}^{3}$, calcium hardness $5.6-7.3$ $\mathrm{mg}-\mathrm{eq} / \mathrm{dm}^{3}$, alkalinity $1.4-2.2 \mathrm{mg}-\mathrm{eq} / \mathrm{dm}^{3}$, iron concentration $3.2-4.2 \mathrm{mg} / \mathrm{dm}^{3}$, concentration of chlorides $280.5-368.5 \mathrm{mg} / \mathrm{dm}^{3}$, salt content $1040-1410 \mathrm{mg} / \mathrm{dm}^{3}, \mathrm{pH}$ 6.5-8.1. The corrosion rate was determined using three coupons and three rods; its value for coupons was 0.418 $\mathrm{mm} / \mathrm{year}$, and for the rods $0.918 \mathrm{~mm} /$ year. A significant amount of bacteria and molds (total microbial number is above 105 colonies in $1 \mathrm{~cm}^{3}$ ) was detected in a circulating water. The tests were carried out using Envirochek Contact TVC slides. With such bacterial contamination it is recommended to treat water by microbiocides and purify it from suspended particles and sediments.

The presence of biological contaminations in the circulating water of test bench is confirmed by a considerable growth of flora (more than 105 colonies in $\mathrm{cm}^{3}$ ), which took place after 7-8 days of research.

At the second stage we used the first set of reagents: PuroTech iChem 2232 (hereinafter reagent 1) in combination with PuroTech iChem 2200 corrosion inhibitor (IC 1) and PuroTech 62, PuroTech 63, PuroTech 68 biocides (microbiocides 1, 2 and 3, respectively). The water volume at the test bench was $130 \mathrm{dm}^{3}$. In the beginning of the experiments the shock doses of tested reagents were added to the tank: reagent $1-100 \mathrm{mg} / \mathrm{dm}^{3}$, microbiocide $1-10 \mathrm{mg} / \mathrm{dm}^{3}$, IC $1-30 \mathrm{mg} / \mathrm{dm}^{3}$. Ocasionally the value of $\mathrm{pH}$ was corrected by adding $20 \%$ solution of sodium hydroxide (to increase $\mathrm{pH}$ to 7.0 ).

Reagent 1 is a mixture of zinc, phosphates, phosphonates and polymer dispersants. It is a complex inhibitor of corrosion and scale formation. Phosphonates and polymers which are used at $\mathrm{pH}=7.5-9.0$ dissolve calcium carbonate.

IC 1 is a mixture of zinc and phosphoric acid which is effective at $\mathrm{pH}=7.5-8.5$. It is used together with the inhibitor of scale formation in large systems of circulating water supply.

Microbiocide 1 is a fast-acting, stabilized miocrobiocide based on bromine compounds, which is effective in neutral and alkaline media. Microbiocides 2 and 3 liquid organic product based on quaternary ammonium salts. They are effective within a wide range of $\mathrm{pH}$ values. All microbiocides are low-toxic and have a short period of biodegradation.

The results of circulating water analysis at the second stage are: total hardness $9.1-12.2 \mathrm{mg}-\mathrm{eq} / \mathrm{dm}^{3}$, calcium hardness $5.6-7.3 \mathrm{mg}$-eq/ $/ \mathrm{dm}^{3}$, alkalinity $1.2-4.0 \mathrm{mg}-\mathrm{eq} / \mathrm{dm}^{3}$, iron concentration $1.1-2.8 \mathrm{mg} / \mathrm{dm}^{3}$, zinc concentration $1.54-11.43 \mathrm{mg} / \mathrm{dm}^{3}$, concentration of chlorides $246.3-388.0 \mathrm{mg} / \mathrm{dm}^{3}$, phosphates concentration $1.6-12.6 \mathrm{mg} / \mathrm{dm}^{3}$, salt content $855-1410 \mathrm{mg} / \mathrm{dm}^{3}$, $\mathrm{pH}$ 4.35-8.25. The corrosion rate for coupons was 
$0.180 \mathrm{~mm} / \mathrm{year}$, and for the rods $0.739 \mathrm{~mm} / \mathrm{year}$. Total microbial number was within 10-100.

At the third stage of investigations we used socalled reference specimens and a heating element. The following set of reagents was used: PuroTech iChem 2132 (hereinafter reagent 2a), consisting of the inhibitor of scale formation ISF 1 and corrosion inhibitor IC 2. Reagent 2a is an aqueous solution of polymer and zinc phosphonates, which dissolves calcium carbonate deposits. Each component was loaded in such a ratio that the amount of regent $2 \mathrm{a}$ in circulating water was equal to $100 \mathrm{~g} / \mathrm{m}^{3}$. Microbiocides 1, 2 and 3 were added to the circulating water at intervals of 1 week to exclude the adaptation of microorganisms.

IC 2 is a complex corrosion inhibitor used for circulating cooling systems. It is used to regulate the zinc content in water in combination with the agents preventing the formation of deposits on the contacting surfaces. IC 2 is used within the $\mathrm{pH}$ range of 7.3-8.5.

ISF 1 is an inhibitor of scale formation used in the systems with calcium content of $20 \mathrm{mg}-\mathrm{eq} / \mathrm{dm}^{3}$ and alkalinity of $6-10 \mathrm{mg}-\mathrm{eq} / \mathrm{dm}^{3}$. It involves the higheffective polymer and may be used for the systems with high concentration of phosphates in makeup water at high temperatures. Corrosion protection is provided by organophosphate derivatives which bind areas of iron corrosion, as well as by maintaining high alkalinity.

The results of circulating water analysis at the third stage are: total hardness $12.7-15.7 \mathrm{mg}-\mathrm{eq} / \mathrm{dm}^{3}$, calcium hardness $4.7-6.2 \mathrm{mg}-\mathrm{eq} / \mathrm{dm}^{3}$, alkalinity $4.0-8.5 \mathrm{mg}-\mathrm{eq} / \mathrm{dm}^{3}$, iron concentration $1.1-2.8 \mathrm{mg} / \mathrm{dm}^{3}$, zinc concentration $0.57-2.74 \mathrm{mg} / \mathrm{dm}^{3}$, concentration of chlorides 383.0-583.0 $\mathrm{mg} / \mathrm{dm}^{3}$, phosphates concentration $0-1.37 \mathrm{mg} / \mathrm{dm}^{3}$, salt content $1360-1580 \mathrm{mg} / \mathrm{dm}^{3}, \mathrm{pH}$ 7.37-8.50. The corrosion rate for coupons was 0.066 $\mathrm{mm} /$ year, and for the rods $0.051 \mathrm{~mm} / \mathrm{year}$.

Ionite was placed into a measuring cell (U-shaped tube) and equalized with the investigated solution by turns (solutions of $0.1-0.5 \mathrm{M}$ were investigated). The dependencies of reverse resistance of neat solution and ionite-solution system on the solution concentration should be plotted at the same diagram. The intersection of the dependencies allows to determine the concentration of conductive solution (under which the concentration of electrical conductivity is the same as for ionite).

Then the resin was transferred to a centrifuge cell (ion exchange cell with a porous bottom and two platinum electrodes, soldered against each other in the cell wall). The equilibrium solution was removed by centrifugation for $15 \mathrm{~min}$ at 373 -fold increase in gravity. Cell resistance $\left(\mathrm{R}_{\mathrm{x}}\right)$ was measured using the alternating current bridge $(1000 \mathrm{~Hz})$. The value of resistance was used to calculate the electrical conductivity of ionite. The obtained results make it possible to study the concentration dependence of resin electrical conductivity in $\mathrm{NaCl}$ solution.

\section{Results and Discussion}

To characterize the behavior of water in relation to scale formation and corrosion the Langelier (LSI) and Ryznar (RSI) indices are used. The first one estimates the behavior of water relative to calcium carbonate. Under specific chemical conditions of the water system a thin layer of sediment is deposited upon the surface of the tube and protects it from corrosion. The formation of such film increases the service life of pipes.

At LSI $>0$ the circulating water is disposed to deposits formation. Using reagents with dispersants (reagent 1 and ISF 1) it is possible to carry out the process even at $\mathrm{LSI}=3.0$. Since dispersants are deactivated by suspended compounds, water should be additionally filtered. At LSI $<0$ the circulating water is sucseptible to dissolve carbonate. The majority of corrosion inhibitors for circulating water supply systems is designed for neutral or alkaline medium, where they contribute to the formation of a protecting film of solid calcium carbonate and zinc. The LSI values calculated depending on time at $313 \mathrm{~K}$ are shown in Fig. 1. (1) [4]:

The Langelier index is calculated according to Eq.

$$
\mathrm{LSI}=\mathrm{pH}+K_{t}+K_{a}+K_{h}-K s
$$

where $\mathrm{pH}-\mathrm{pH}$ value of water; $K_{t}-$ temperature coefficient; $K_{a}-$ alkaline coefficient; $K_{h}-$ hardness coefficient; $K_{s}$ - coefficient of salt content.

The Ryznar index characterizes the circulation water corrosivity with respect to the steel. It is calculated according to Eq. (2):

$$
\mathrm{RSI}=2 \mathrm{LSI}-\mathrm{pH}
$$

All coefficients were taken from the special literature [13-16] depending on water parameters. Variation of indices at $313 \mathrm{~K}$ is represented in Fig. 2.

The value of LSI $<6.0$ (first stage) indicates the low corrosiveness of water in regard to steel but it is susceptible to scale formation. While using IC 1 the Ryznar index exceeds the value of 6.5 and circulating water is more aggressive to steel. While using IC 2 (third stage) RSI varies within 5.8-6.2. Thus, IC 2 allows to control the corrosiveness of water.

It is seen from the figures that at the first stage the circulating water is susceptible to form scales; at the second stage (as a result of using result 1 and IC 1) carbonates are dissolved; at the third stage (as a result of using ISF 1 and IC 1) water is stable.

At the first stage (without reagents) the corrosion rate is maximal: $0.418 \mathrm{~mm} /$ year for coupons and 0.918 $\mathrm{mm} / \mathrm{year}$ for rods. The reason is intensive oxidation reaction of metal elements under the effect of various factors, including microorganisms. Inhibitors of corrosion and scale formation, as well as microbiocides show a positive effect. 


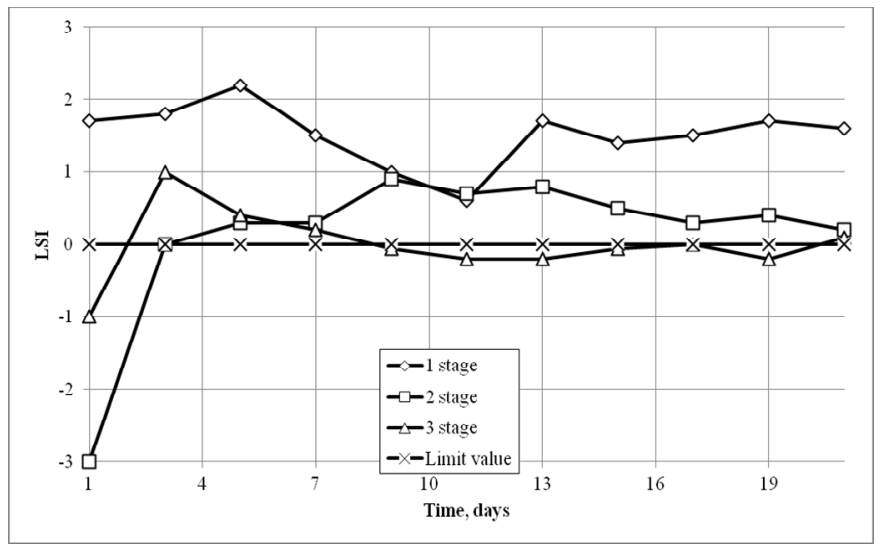

Fig. 1. Variation of LSI depending on time

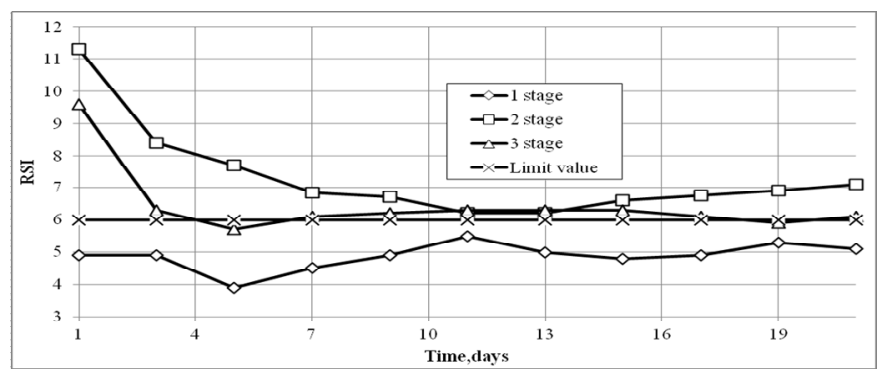

Fig. 2. Variation of RSI depending on time

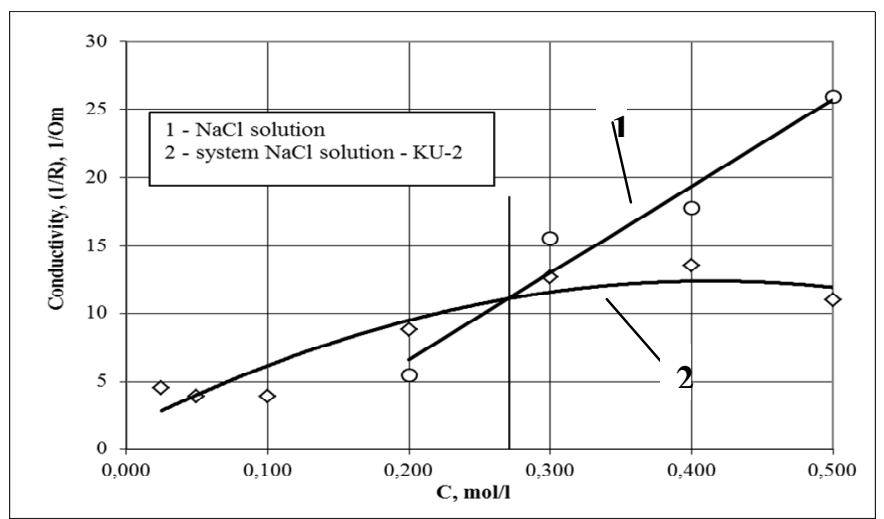

Fig. 3. Determination of isoconductivity point for $\mathrm{KU}-2$ resin in $\mathrm{NaCl}$ solution in $\mathrm{U}$-shaped tube

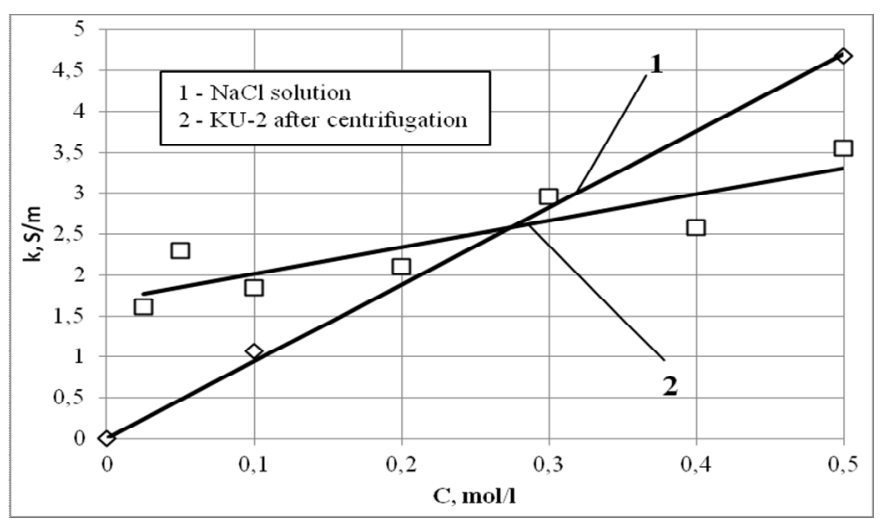

Fig. 4. Concentration dependence of KU-2 electric conductivity 
At the second stage (water treatment by PuroTech iChem 2232, PuroTech iChem corrosion inhibitor and PuroTech 62, PuroTech 63, PuroTech 68 microbiocides) scale formation and corrosivity of the circulating water decrease: the corrosion rate is $0.180 \mathrm{~mm} /$ year for coupons and $0.739 \mathrm{~mm} /$ year for rods.

The best result is obtained at the third stage (water treatment by PuroTech iChem 2132A). The main reason is that aqueous solutions of zinc phosphonates and polymer contribute to dissolution of calcium carbonate and microbiocides prevent reproduction and deposition of microorganisms over the metal surface. The recommended dose of microbiocides is $50 \mathrm{mg} / \mathrm{dm}^{3}$. The rate of steel corrosion decreases to $0.066 \mathrm{~mm} /$ year for flat coupons and $0.051 \mathrm{~mm} / \mathrm{year}$ for round ones.

It should be noted that using the reagents at the third stage the corrosion protection is provided by certain organo-phosphate derivatives which most effectively bind the areas of iron corrosion, as well as by maintaining high alkalinity. Thus, it is recommended to use inhibitors of corrosion and scale formation at this stage to improve the quality of circulating water.

The dependencies for pure solution (1) and ionitesolution system (2) for determining the concentration of isoconductive solution are presented in Fig. 3. The intersection of the obtained dependencies allows to determine the concentration of isoconductive solution, which is equal to $0.27 \mathrm{~mol} / \mathrm{dm}^{3}$.

Using the dependence for specific conductivity of sodium chloride $y=9.2686 x+0.0623$ [15] we obtain $k_{\text {iso }}=2.56 \mathrm{Ohm}^{-1} \mathrm{~m}^{-1}$.

The cell constant is calculated according to Eq. (3):

$$
\Gamma=k_{\text {iso }} \cdot R_{\text {iso }}
$$

where $\Gamma$ - cell constant determined in accordance with known electric conductivity of ionite in the isoconductivity point; $R_{i s o}$ - resistance of the cell with resin which is in equilibrium with isoconductive solution and measured after centrifugation.

Concentration dependence of KU-2 resin electric conductivity is given in Fig. 4.

\section{Conclusions}

The obtained results confirm the advisability of circulating water treatment at first by the inhibitor of scale formation ISF 1 and corrosion inhibitor IC 2 and then by PuroTech iChem 2132A complex reagent. PuroTech 62, PuroTech 63 and PuroTech 68 microbiocides must be used by turns to avoid microorganisms adaptation.

Using PuroTech iChem 2132A the corrosion rate decreases by 6 times (to $0.066 \mathrm{~mm} / \mathrm{year}$ ) for plain coupons and by 18 times (to $0.051 \mathrm{~mm} /$ year) - for round rods. Higher protective effect of the inhibitor at the third stage compared with that at the first and second stages is provided by the increase in salt content by $15-20 \%$.
Thus, the inhibitors of corrosion and scale formation in the circulating water supply system improve the circulating water quality, allow to decrease the corrosion rate and increase equipment life.

The research results of KU-2 electrical conductivity, which will be used for intermembrane filling during electrodialysis, allow to determine cell constant and concentration dependence of KU-2 electrical conductivity. These values may be used to calculate the real processes.

\section{References}

[1] Ricroft R., Regens L., Dietz T.: Risk Analysis, 1998, 3, 415.

[2] Shmandiy V., Kharlamova E., Rigas T.: Hihiena i Sanitaria, 2015, 7, 90.

[3] Grittenden J., Trussell R., Hand D., Kerry K., Tchobanoglous G.: MWH's Water Treatment: Principles and Design. Wiley \& Sons, NJ 2012. https://doi.org/10.1002/9781118131473

[4] Belikov S. (Ed.): Vodopodgotovka. Akwa-Term, Moskow 2007.

[5] Bezdenezhnykh L., Sviatenko A.: Ecologichna Bezpeka, 2015, 2, 78.

[6] Homelia N., Shabliy T., Nosacheva Yu.: Ecotechnol. i Resursozber., 2004, 4, 55.

[7] Xu F., Innocent C., Pourcelly G.: Separ. Purif. Technol., 2005, 1, 17. https://doi.org/10.1016/j.seppur.2004.09.009

[8] Malakhov I., Poletaev L., Kosmodaminsky V. et al.: Khim. i Techn. Vody, 1992, 14, 298.

[9] Wisniewski J.: Desalination, 2007, 1-3, 251. https://doi.org/10.1016/j.desal.2006.11.008

[10] Ayala-Bribiesca E., Pourcelly G., Bazinet L.: J. Colloid. Interf. Sci., 2007, 1, 182. https://doi.org/10.1016/j.jcis.2006.11.012

[11] Nosachova Yu., Zelenyuk O., Homelia M.: Khim. Ing., Ecol., Resursozber., 2010, 1, 48.

[12] Shaposhnik V., Kuzminykh V., Grigorchuk O., Vasilieva V.: J. Membr. Sci., 1997, 133, 27. https://doi.org/10.1016/S03767388(97)00063-X

[13] http://sts-sib.ru/uploads/file/1dab73619b39e261fcba35a46793dcle_ 55559c3848e09.pdf/

[14] Tchobanoglous G., Burton F., Stensel H.: Wastewater Engineering: Treatment and Reuse, $4^{\text {th }}$ edn. Metcalf $\&$ Eddy Inc., McGraw-Hill, New York 2003.

\section{Received: M arch 09, 2016 / Revised: April 24, 2016 / Accepted: July 12, 2016 \\ ДОСЛІДЖЕНЯ МЕТОДІВ СТАБІЛІЗАЦІї СОЛЬОВОГО СКЛАДУ ВОДИ СИСТЕМ ЗВОРОТНОГО ВОДОПОСТАЧАННЯ}

Анотація. Досліджсено вплив певних інгібіторів корозії та мікробіочидів в системах зворотного водопостачання на швидкість корозї конструкиійних матеріалів. Показано, щзо застосування суміші водних розчинів фосфонатів цинку, спеціального полімерного дисперсанту та мікробіочидів на основі сполук брому $і$ четвертинних амонієвих солей забезпечує розчинення відкладень карбонату кальиію та швидкість корозії стальних матеріалів на мінімально можливому рівні. Запропоновано рачіональні режсии хімічного оброблення води в системах зворотного водопостачання, шо приводять до підвищення надійності їх експлуатаџії. Досліджена електропровідність смоли

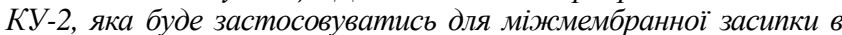
електродіалізі підживюючої води системи зворотного водопостачання з метою запобігання концентрування солей.

Ключові слова: зворотне водопостачання, корозійні прочеси, інгібітори корозії, мікробіочиди, електродіаліз, міжмембранна засипка. 